\title{
High frequency of mutations in MODY and mitochondrial genes in Scandinavian patients with familial early-onset diabetes
} \author{
T. Tuomi ${ }^{1}$, L. Groop ${ }^{1}$ \\ ${ }^{1}$ Department of Endocrinology, University Hospital MAS, University of Lund, Malmö, Sweden \\ ${ }^{2}$ Department of Paediatrics, University Hospital MAS, University of Lund, Malmö, Sweden \\ ${ }^{3}$ Department of Paediatrics, Helsinki University Hospital, Helsinki, Finland \\ ${ }^{4}$ Department of Internal Medicine, University Hospital, Uppsala, Sweden
}

M. Lehto ${ }^{1}$, C. Wipemo ${ }^{1}$, S.-A. Ivarsson ${ }^{2}$, C. Lindgren ${ }^{1}$, M. Lipsanen-Nyman ${ }^{3}$ J. Weng ${ }^{1}$, L. Wibell ${ }^{4}$, E. Widén ${ }^{1}$

\section{Abstract}

Aims/hypothesis. To investigate the contribution of mutations in maturity-onset diabetes of the young (MODY) and mitochondrial genes to early-onset diabetes with a strong family history of diabetes in a cohort with a high prevalence of Type I (insulin-dependent) diabetes mellitus.

Methods. Screening for sequence variants in the hepatocyte nuclear factor ( $H N F)-4 \alpha$ (MODY1), glucokinase (MODY2), HNF-1 $\alpha$ (MODY3) genes and mitochondrial DNA was carried out in 115 Finnish and Swedish patients with early-onset ( $\leq 40$ years) diabetes using the single strand conformation polymorphism (SSCP) technique and direct sequencing. Allele frequencies were compared with 118 patients with onset of diabetes Type II (non-insulin-dependent) diabetes mellitus after the age of 40 and 92 non-diabetic control subjects without a family history of diabetes.

Results. In total 52 sequence variants were found in the $H N F-1 \alpha, H N F-4 \alpha$ and glucokinase genes, 12 of which were considered as MODY mutations. Three families had the A3243G mutation in the mitochondrial $t R N A^{L e u}$ gene, which resulted in an overall prevalence of these mutations of $13 \%$.

Conclusion/interpretation. Among 115 Scandinavian families, mutations in the $H N F-1 \alpha$ gene represented the most common cause of familial early-onset ( $\leq 40$ years) diabetes: MODY3 $(5.2 \%)$ more than MODY2 (3.5\%) more than MIDD (2.6\%) more than MODY1 (1.7\%). [Diabetologia (1999) 42: 1131-1137]

Keywords Glucokinase, HNF-1, HNF-4, MODY, MIDD, genetics.
Maturity-onset diabetes of the young (MODY) is a monogenic form of Type II (non-insulin-dependent) diabetes mellitus. It is inherited in autosomal dominant fashion and expressed at early adult life. To date, mutations in five different genes are known to cause MODY: the hepatocyte nuclear factor $(H N F)$ $-4 \alpha$ gene on chromosome 20 (MODY1), the glucoki-

Received: 3 March 1999 and in revised form: 14 May 1999

Corresponding author: M. Lehto, Department of Endocrinology, Wallenberg Laboratory (Entrance 46), MAS, S-20502 Malmö, Sweden

Abbreviations: GAD-Ab, Glutamic acid decarboxylase antibodies; $G C K$, glucokinase; HNF, hepatocyte nuclear factor; MIDD, maternally inherited diabetes and deafness; MODY, maturity-onset diabetes of the young. nase $(G C K)$ gene on chromosome 7 (MODY2), the $H N F-1 \alpha$ gene on chromosome 12 (MODY3), the insulin promoter factor 1 (IPF1) gene on chromosome 13 (MODY4), and the $H N F-1 \beta$ gene on chromosome 17 (MODY5) [1].

A maternally inherited mutation A3243G in the mitochondrial $t R N A^{\text {Leu }}$ gene was originally described in patients with the MELAS syndrome (mitochondrial encephalomyopathy, lactic acidosis and stroke-like episodes). However, this mutation is also associated with several other phenotypes including diabetes and hearing loss (MIDD, maternally inherited diabetes and deafness) [2].

Maturity-onset diabetes of the young is thought to explain about $2 \%$ of all diabetes [1] but its true prevalence in many populations is still not clear. The highest prevalence of Type I (insulin-dependent) dia- 
Table 1. Scandinavian families with early-onset diabetes; clinical characteristics of diabetic patients and non-diabetic control subjects

\begin{tabular}{|c|c|c|c|}
\hline & $\begin{array}{l}\text { Early-onset } \\
\text { diabetic patients }\end{array}$ & $\begin{array}{l}\text { Late-onset } \\
\text { diabetic patients }\end{array}$ & $\begin{array}{l}\text { Non-diabetic } \\
\text { control subjects }\end{array}$ \\
\hline Subjects $(\mathrm{M} / \mathrm{F})$ & $115(55 / 60)$ & $118(48 / 70)$ & $92(47 / 45)$ \\
\hline Age (year) & $45 \pm 14$ & $62 \pm 7$ & $61 \pm 9$ \\
\hline Age at onset (year) & $25 \pm 10$ & $52 \pm 6$ & - \\
\hline Duration (year) & $20 \pm 13$ & $10 \pm 7$ & - \\
\hline BMI $\left(\mathrm{kg} / \mathrm{m}^{2}\right)$ & $26.5 \pm 5.5$ & $30.2 \pm 5.2$ & $26.0 \pm 4.2$ \\
\hline $\begin{array}{l}\text { Systolic BP }(\mathrm{mm} \mathrm{Hg}) \\
\text { Diastolic BP }(\mathrm{mm} \mathrm{Hg})\end{array}$ & $\begin{array}{r}137 \pm 25 \\
79 \pm 10\end{array}$ & $\begin{array}{r}145 \pm 21 \\
82 \pm 10\end{array}$ & $\begin{array}{r}133 \pm 19 \\
77 \pm 10\end{array}$ \\
\hline $\mathrm{HbA}_{1 \mathrm{c}}(\%)$ & $8.3 \pm 1.6$ & $7.9 \pm 1.7$ & $5.0 \pm 0.5$ \\
\hline $\begin{array}{l}\text { FB-Glucose }(\mathrm{mmol} / \mathrm{l}) \\
\text { 2h-Glucose }(\mathrm{mmol} / \mathrm{l})\end{array}$ & $\begin{array}{r}9.6 \pm 3.9 \\
12.2 \pm 2.6\end{array}$ & $\begin{array}{r}8.9 \pm 2.9 \\
13.9 \pm 3.6\end{array}$ & $\begin{array}{l}4.6 \pm 0.4 \\
5.0 \pm 1.0\end{array}$ \\
\hline GAD-Ab positive $(\%)$ & 23 & 9 & 3 \\
\hline $\begin{array}{l}\text { Treatment: } \\
\text { Insulin } \\
\text { Oral agents } \\
\text { Diet }\end{array}$ & $\begin{array}{l}86(75 \%) \\
16(14 \%) \\
13(11 \%)\end{array}$ & $\begin{array}{l}45(38 \%) \\
49(42 \%) \\
24(20 \%)\end{array}$ & $\begin{array}{l}- \\
- \\
-\end{array}$ \\
\hline
\end{tabular}

Values are presented as means \pm SD. FB, fasting blood; FS, fasting serum; WHR, waist-to-hip ratio

betes mellitus has been reported in Finland and Sweden [3]. As both MODY and MIDD mostly present with a young onset and insulin deficient phenotype, it is probable that patients with these monogenic types of diabetes are frequently misclassified as having Type I diabetes. The contribution of these monogenic forms of diabetes to the high prevalence of early-onset diabetes in Finland and Sweden is not known. The aim of our study was to establish the prevalence of MODY and mitochondrial mutations in 115 patients diagnosed with diabetes at 40 years of age or younger and with a strong family history of diabetes.

\section{Materials and methods}

Subjects and measurements. In total 115 families with early-onset diabetes were selected from 1350 Swedish and Finnish families. Of them, there were 3 families with 1 patient, 41 families with 2 patients, 71 families with 3 or more patients diagnosed with diabetes at 40 years of age or younger [4]. On average, the pedigrees included 9 subjects with four diabetic patients per family. From each family, one patient with early-onset ( $\leq 40$ years) diabetes was chosen for mutation screening. Of the 115 selected probands, $80 \%$ had a first-degree relative diagnosed with diabetes at 40 years of age or younger. There were 48 probands who had originally been diagnosed with Type I diabetes by their physicians. Of them, $29 \%$ (11/38) were positive for glutamic acid decarboxylase antibodies (GAD-Ab). About $66 \%(23 / 35)$ of these patients had no measurable fasting serum $\mathrm{C}$ peptides $(>0.03 \mathrm{nmol} / \mathrm{l})$. Of the 115 families 12 fulfilled also the classical MODY criteria: autosomal dominant inheritance of diabetes in three generations and two diabetic patients with age at onset of 25 years or younger. In total 20 families fulfilled less stringent MODY criteria (diabetes in three generations and at least one diabetic patient with age at onset $\leq 25$ years). The allele frequency of new sequence variants in the cohort was tested in 92 non-diabetic control subjects. In addition, the allele frequency of the $H N F-1 \alpha$ gene variation A98V was tested in 118 unrelated Finnish Type II diabetic patients diagnosed with diabetes after the age of 40 years. Basic clinical characteristics of study subjects are presented in Table 1 . Studies were approved by the local ethics committees. Concentrations of glucose, insulin, C-peptide, $\mathrm{HbA}_{1 \mathrm{c}}$, lipids and $\mathrm{GAD}-\mathrm{Ab}$ were determined as described before [5].

Mutation screening of MODY genes. Mutation screening of the $H N F-4 \alpha, G C K$ and $H N F-1 \alpha$ genes were done with the single strand conformation polymorphism (SSCP) technique and by direct sequencing. Primer sequences are presented in Table 2. The sequencing was performed with a Thermo Sequenase dye terminator cycle sequencing pre-mix kit (Amersham Life Science, Cleveland, Ohio, USA) according to manufacturers' instructions using ABI373 A DNA Sequencer (Applied Biosystems, Foster City, Calif., USA). Each specific fragment was sequenced with the original primers in both directions and analysed using Sequencer software package (Gene Codes Corporation, Ann Arbor, Mich., USA).

Detection of the A3243G mutation in the mitochondrial $t R$ $N A^{\text {Leu }}$ gene. Total DNA was isolated from peripheral blood lymphocytes and amplified by using primers specific to mtDNA [2]. A $427 \mathrm{bp}$ fragment, labelled with $\left[\alpha{ }^{32} \mathrm{P}\right] \mathrm{dCTP}$ during PCR cycling, was digested with Apa I at $37^{\circ} \mathrm{C}$ for $8 \mathrm{~h}$. Samples were electrophoresed with constant power $(50 \mathrm{~W})$ on 
Table 2. Scandinavian families with early-onset diabetes; primers used for amplification of $H N F-4 \alpha, G C K$ and $H N F-1 \alpha$ genes

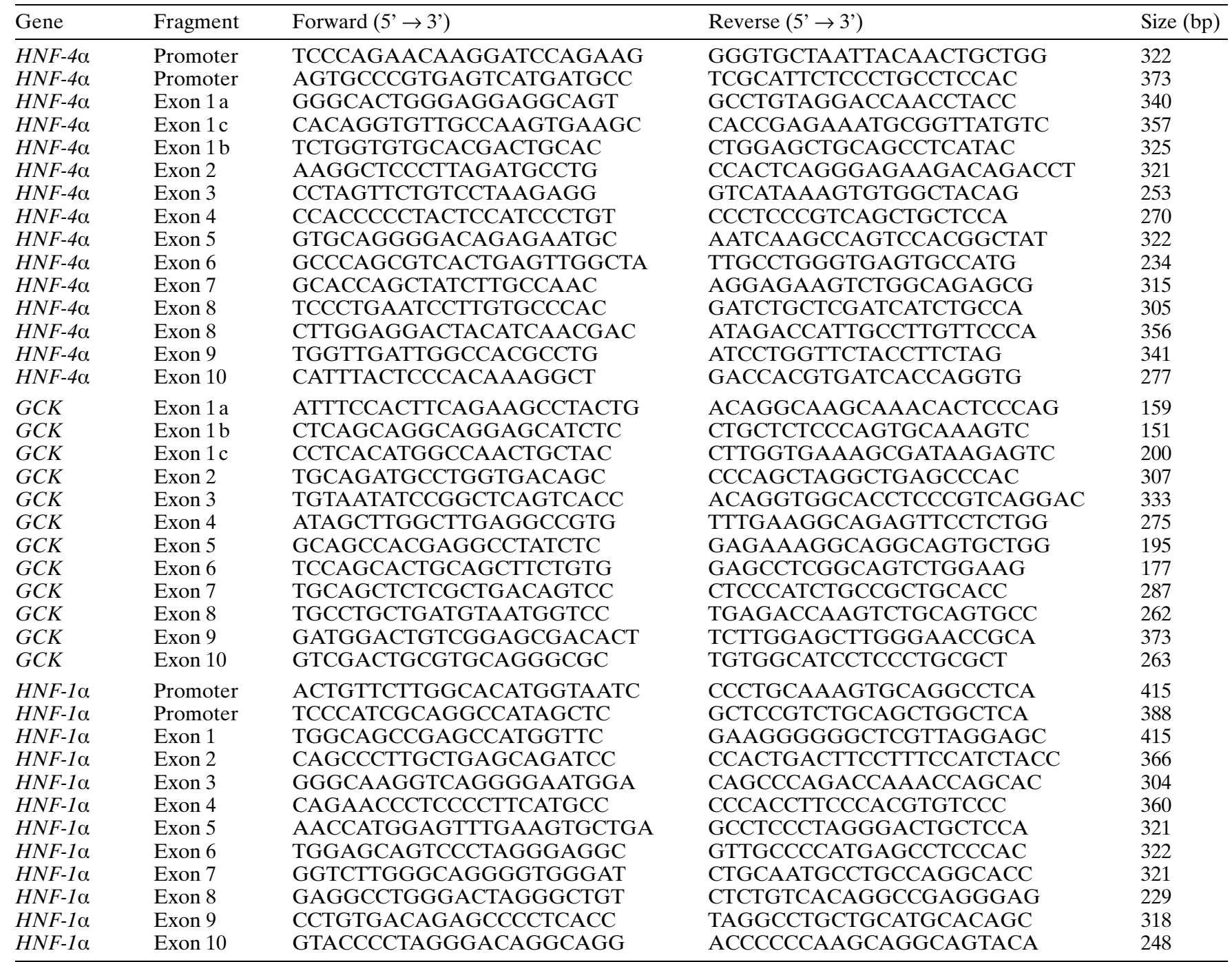

$5 \%$ acrylamide gel under denaturing conditions for $3.5 \mathrm{~h}$. Gels were then dried and exposed to films at $-70^{\circ} \mathrm{C}$ for $1-3$ days.

Statistics. Data are expressed as means \pm SD. The significance of frequency differences between groups was tested by Yates corrected chi-square test (BMDP Statistical Software, Los Angeles, Calif., USA). A $p$ value less than 0.05 was considered statistically significant.

\section{Results}

The mutation screening of $H N F-4 \alpha, G C K$ and $H N F$ $1 \alpha$ genes in the 115 unrelated early-onset diabetic patients resulted in 52 sequence variations, 12 of which were considered as MODY mutations. We found two $H N F-4 \alpha$ (MODY1) mutations, a deletion of two adenines at codon 99 (K99fsdelAA) in exon 3 and an insertion of a valine between codons L328-L329 (V328-329ins) in exon 8. The clinical characterization of the DS-family, carrying the K99fsdelAA mu- tation, has been recently described [6]. We identified four novel mutations in the $G C K$ (MODY2) gene: an amino acid substitution (G72R) in exon 3, two splice site variants (IVS3 $+1 \mathrm{G}>\mathrm{A}$ and IVS3-2A $>$ G) on both sides of intron 3 and one in frame duplication of eight amino acids (133dupY125-D132) in exon 4. We found six mutations in the HNF-1 $\alpha$ (MODY3) gene. Other than three previously reported variations (R131Q, R272 $\mathrm{C}$, and Pro291fsinsC) [7, 8], we identified one amino acid substitution (L107I in exon 1), one insertion (S315fsinsA in exon 4) and one deletion (G375fsdelG in exon 6). In the LS-family, two diabetic R131Q mutation carriers (LS-3 and LS-8) also have a hereditary form of neuropathy, Charcot-Marie Tooth disease type 1 A (CMT1 A) (Fig. 1). An additional three families were found to carry a specific mutation $(\mathrm{A} 3243 \mathrm{G})$ in the mitochondrial $t R N A^{\text {Leu }}$ gene. The MODY and MIDD families are presented in Figure 1. 


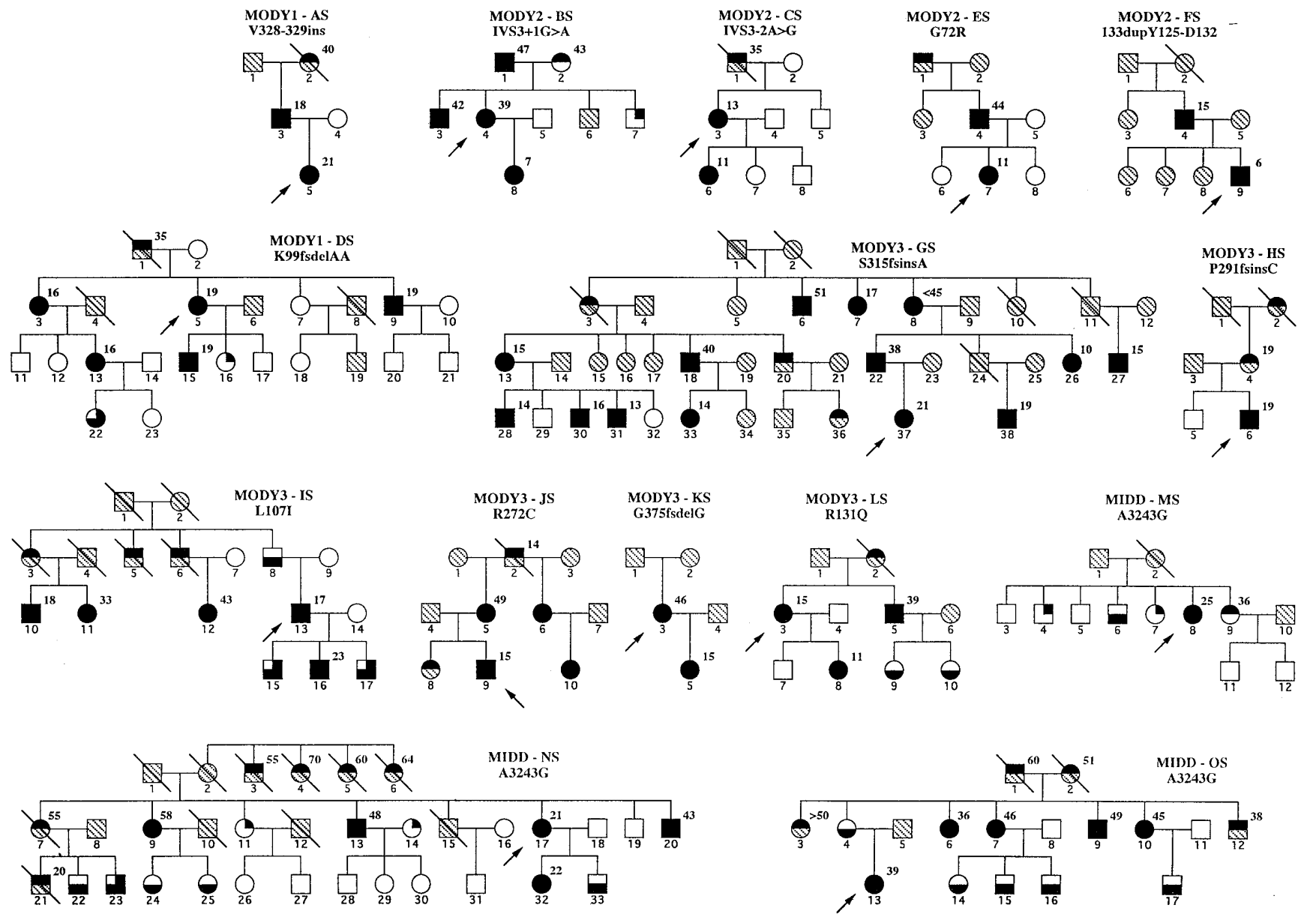

Fig. 1.The pedigree structures of MODY1, MODY2, MODY3 and MIDD families. The probands are indicated with an arrow. Age at onset of diabetes is shown at the upper right corner of the symbol. $\square$ NGT; $\square$ IGT; $\square$ diabetes; $\square$ mutation carrier; $\mathbb{N}$ not tested

Description of another 40 sequence variations in the $H N F-1 \alpha, H N F-4 \alpha$ and glucokinase genes are presented in Table 3. Of note, the Val98 allele in the $H N F-1 \alpha$ gene, was three times more prevalent in the diabetic $(n=115)$ than in the control $(n=92)$ group $(8.7 \%$ vs $2.7 \% ; p=0.02)$. When the subjects were divided according to the country of origin, the frequency of Val98 allele was six times more prevalent among Finnish $(n=68)$ than among Swedish $(n=47)$ diabetic patients $(13.2 \%$ vs $2.1 \%$; $p=0.007)$. The frequency of the Val98 allele was increased compared with 58 Finnish non-diabetic control subjects $(13.2 \%$ vs $3.5 \% ; p=0.01)$. We also tested the frequency of the Val98 allele in 118 unrelated Finnish Type II diabetic patients, who had been diagnosed with diabetes after the age of 40 years. The Val98 allele was more common among early-onset ( $\leq 40$ year) than among late-onset ( $>40$ year) diabetic patients $(13.2 \%$ vs $4.2 \% ; p=0.003)$.
Clinical characteristics of diabetic patients in $M O D Y 1-3, \operatorname{MODY}(X)$ and MIDD families. We found MODY1-3 mutations in 7 out of 12 families fulfilling the classical MODY criteria (see methods). Since the remaining 5 families did not show any mutations in either the IPF1 (MODY4) or the $H N F-1 \beta$ (MODY5) genes (Weng and Lehto, unpublished observations), they were considered as MODY(X) families. Notably, $46 \%(12 / 26)$ of diabetic patients in the MODY(X) families had originally been diagnosed with Type I diabetes and $42 \%(11 / 26)$ had onset at 25 years of age or younger. Among the diabetic mutation carriers tested in MODY1-3 and MIDD families, the proportion of those 25 years of age or younger at onset was $100 \%$ in MODY $1(7 / 7), 68 \%$ in MODY3 (19/28), 60\% in MODY2 (6/10) and $27 \%$ in MIDD (3/11). The clinical characteristics of diabetic patients in MODY1, MODY2, MODY3 (families HS, LS, IS), MIDD and MODY(X) families are summarised in Table 4.

\section{Discussion}

It has been considered that about $10-15 \%$ of patients with onset of diabetes before the age of 40 years has Type II diabetes and another $10 \%$ is unclassifiable 
Table 3. The $H N F-4 \alpha, G C K$ and $H N F-1 \alpha$ gene variations in patients with early-onset ( $\leq 40$ years) diabetes

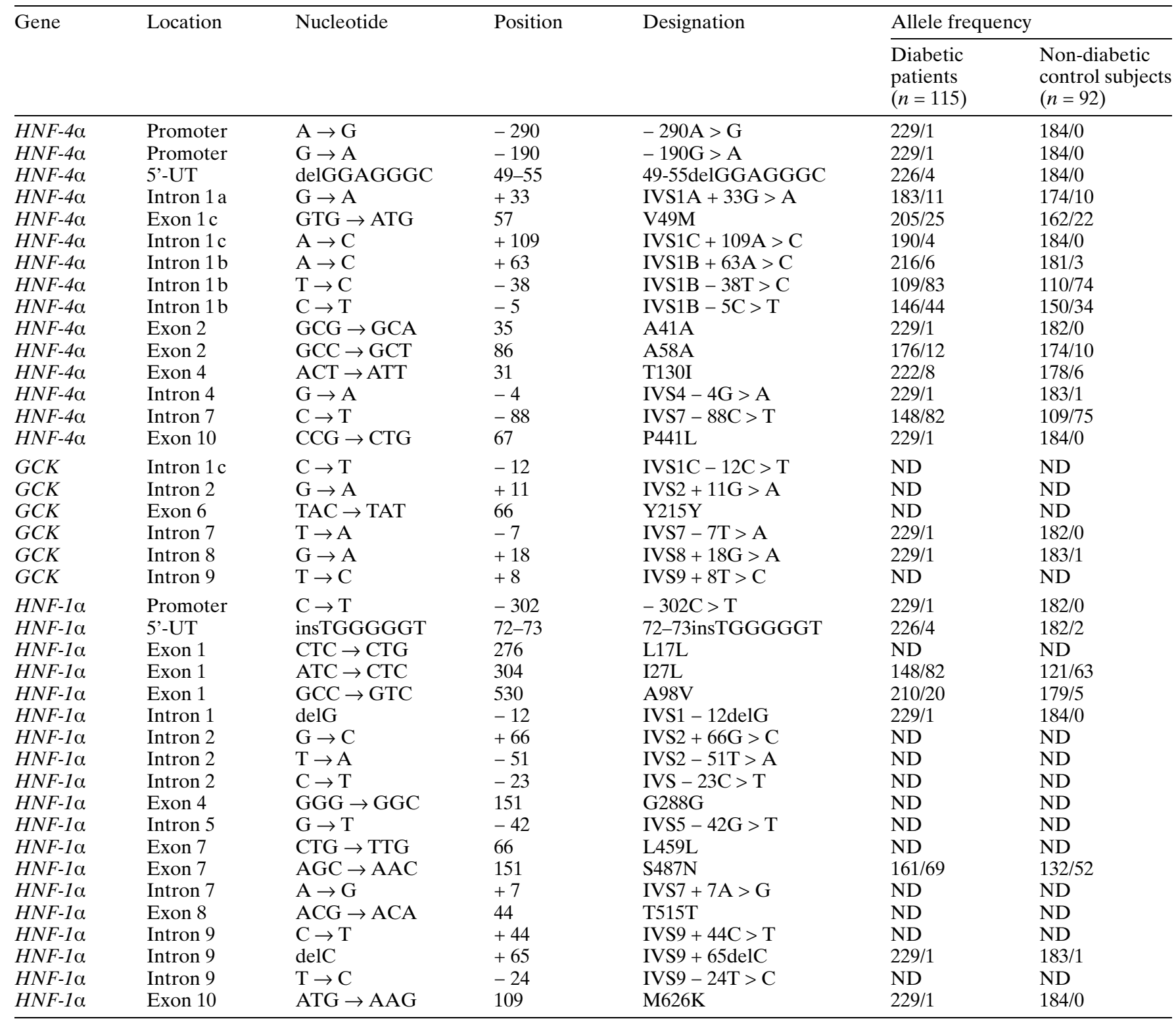

5-UT, 5'-untranslated region. ND, not determined

[9]. Our study showed that $13 \%$ of patients in this age group had mutations in MODY or mitochondrial genes. These patients were further characterized by a strong family history of diabetes. In addition, 40 other sequence variations in the $H N F-1 \alpha, H N F-4 \alpha$ and glucokinase genes were identified in these patients, but it needs to be shown whether they result in functional defects.

The HNF-1 $\alpha$ amino acid substitution A98V has been associated with impaired insulin and C-peptide responses to glucose in Danish middle-aged control subjects [10]. Among Finnish subjects with early-onset diabetes, the prevalence of the Val98 allele was about $13 \%$, which was statistically significantly higher than in non-diabetic control subjects $(3.5 \%)$ or in patients with late-onset Type II diabetes $(4.2 \%)$. In the Danish cohort, the prevalence of the Val98 allele was $3.7 \%$ in late-onset Type II diabetes and $4.4 \%$ in control subjects [10].

Among the 12 classically defined MODY-families, 7 were found to carry a MODY-mutation. Since the remaining 5 families did not show mutations in the IPF1 (MODY4) or HNF-1 $\beta$ (MODY5) genes (Weng and Lehto, unpublished observations), they were considered as MODY(X) families. Low fasting Cpeptide concentrations and insulin requirement point in the $\operatorname{MODY}(\mathrm{X})$ patients at a severe pancreatic beta-cell dysfunction. Noteworthy, about half of the patients in the MODY $(\mathrm{X})$ families had originally been given a diagnosis of Type I diabetes. Whether diabetes in these MODY $(\mathrm{X})$ families is monogenic or polygenic in origin remains to be determined. 
Table 4. Clinical characteristics of diabetic patients in MODY1, MODY2, MODY3, MIDD and MODY(X) families

\begin{tabular}{|c|c|c|c|c|c|}
\hline & $\begin{array}{l}\text { MODY1 } \\
\text { (2 families) }\end{array}$ & $\begin{array}{l}\text { MODY2 } \\
\text { (4 families) }\end{array}$ & $\begin{array}{l}\text { MODY3 } \\
\text { (3 families) }\end{array}$ & $\begin{array}{l}\text { MIDD } \\
\text { (3 families) }\end{array}$ & $\begin{array}{l}\text { MODY(X) } \\
\text { (5 families) }\end{array}$ \\
\hline Subjects $(\mathrm{M} / \mathrm{F})$ & $3 / 4$ & $4 / 5$ & $5 / 4$ & $3 / 8$ & $14 / 7$ \\
\hline Age (year) & $46 \pm 13$ & $31 \pm 19$ & $43 \pm 14$ & $50 \pm 12$ & $51 \pm 22$ \\
\hline Age at onset (year) & $18 \pm 2$ & $17 \pm 12$ & $24 \pm 10$ & $38 \pm 12$ & $37 \pm 20$ \\
\hline Duration (year) & $28 \pm 15$ & $15 \pm 9$ & $20 \pm 12$ & $12 \pm 13$ & $14 \pm 12$ \\
\hline $\mathrm{BMI}\left(\mathrm{kg} / \mathrm{m}^{2}\right)$ & $24.8 \pm 1.5$ & $24.0 \pm 5.8$ & $23.1 \pm 3.4$ & $23.6 \pm 3.7$ & $26.2 \pm 4.8$ \\
\hline FB-Glucose $(\mathrm{mmol} / \mathrm{l})$ & $7.8 \pm 3.1$ & $6.6 \pm 0.8$ & $8.5 \pm 2.7$ & $8.2 \pm 2.7$ & $8.8 \pm 4.6$ \\
\hline FS-C peptide (nmol/l) & $0.08 \pm 0.04$ & $0.26 \pm 0.12$ & $0.22 \pm 0.22$ & $0.56 \pm 0.45$ & $0.31 \pm 0.32$ \\
\hline $\begin{array}{l}\text { Cholesterol }(\mathrm{mmol} / \mathrm{l}) \\
\text { Triglycerides }(\mathrm{mmol} / \mathrm{l}) \\
\text { HDL-Chol. }(\mathrm{mmol} / \mathrm{l})\end{array}$ & $\begin{array}{l}4.88 \pm 1.26 \\
0.94 \pm 0.46 \\
1.47 \pm 0.36\end{array}$ & $\begin{array}{l}5.41 \pm 1.03 \\
1.22 \pm 0.35 \\
1.34 \pm 0.30\end{array}$ & $\begin{array}{l}5.72 \pm 1.27 \\
1.35 \pm 0.47 \\
1.41 \pm 0.36\end{array}$ & $\begin{array}{l}5.18 \pm 0.75 \\
2.12 \pm 1.06 \\
1.21 \pm 0.43\end{array}$ & $\begin{array}{l}4.39 \pm 1.21 \\
1.33 \pm 0.88 \\
1.13 \pm 0.32\end{array}$ \\
\hline GAD-Ab positive & $0 / 6(0 \%)$ & $1 / 7(14 \%)$ & $0 / 8(0 \%)$ & $2 / 11(18 \%)$ & $3 / 16(19 \%)$ \\
\hline
\end{tabular}

In the MODY1-3 families, diabetic mutation carriers exhibited typical features of MODY, e.g. earlyonset, normal weight, low fasting C-peptide concentrations and a normal lipid profile. Although patients in the MIDD families had a similar BMI as the MODY patients, they tended to have a later onset, higher fasting $\mathrm{C}$-peptide concentrations and diabetic dyslipidaemia. Therefore, the phenotype of the MIDD patients resembled more the phenotype of the insulin resistant Type II diabetic patients. Among the MODY patients, GAD-antibodies were detected in only 1 of $21(4.8 \%)$ subjects, which is similar to the frequency we have reported in Scandinavian non-diabetic subjects $(4.4 \%)$ [11]. Thus, GAD-antibodies do not seem to be a characteristic of MODY patients.

The families in the present study were selected based upon early-onset and family history of diabetes. Of 12 families 5 with a MODY-mutation did not meet the classical MODY-criteria. Of 15 probands with a defined genetic defect 2 had been given a diagnosis of Type I diabetes. Recent studies have shown that about $5-10 \%$ of patients diagnosed with Type I diabetes could carry a mutation in the $H N F-1 \alpha$ gene $[12,13]$. In summary, among 115 families with early-onset ( $\leq 40$ years) diabetes, mutations in the $H N F-1 \alpha$ gene represented the most common cause of diabetes: MODY3 (5.2\%) more than MODY2 (3.5\%) more than MIDD $(2.6 \%)$ more than MODY1 $(1.7 \%)$. When these data were pooled with our previous findings $([5,6,14]$ and unpublished observations), the following distribution of MODY was seen in 26 Scandinavian families: MODY1 (8\%), MODY2 (15\%), MODY3 (58\%) and MODY(X) $(19 \%)$. Of note, about $60 \%$ of the Scandinavian MODY3 families carried a "hotspot" mutation
Pro291fsinsC [14]. A similar frequency of different MODY forms has recently been reported in a British cohort [1]. Recent studies of MODY families have shown that mutations in the IPFI and $H N F-1 \beta$ genes are very rare [15-17], which suggest that other still unknown MODY genes could be identified in the future.

Acknowledgements. We thank M. Svensson, A. Nilsson and A. Berglund for skillful technical assistance. Doctors P.-O. Bitzen, C. Forsblom, K. Majamaa, J.S. Moilanen, P. Muona, and T. Smith are acknowledged for identifying and recruiting the families as well as carrying out the clinical characterization of the families. We also thank the members of the families for their willingness to participate in the studies. The GAD65 cDNA was kindly provided by Drs A. Karlsen and C. Grubin, University of Washington, Seattle, USA. This study was supported by grants from the Anna Lisa and Sven-Eric Lundgrens foundation, Medical Faculty of Lund University, the Royal Physiographic Society in Lund, Swedish Society for Medical Research, the University Hospital MAS funds (M. Lehto), Albert Påhlssons Foundation (M. Lehto, T. Tuomi), the Academy of Finland, Sigrid Juselius Foundation, Swedish Medical Research Council, JDF-Wallenberg grant, and EC Grant BMH4CT95-0662 (L. Groop).

\section{References}

1. Hattersley AT (1998) Heterogeneity in Type 2 diabetes: Lessons from maturity-onset diabetes of the young. Diabetic Reviews International 15: 15-24

2. Van den Ouweland JM, Lemkes HH, Ruitenbeek W et al. (1992) Mutation in mitochondrial tRNALeu(UUR) gene in a large pedigree with maternally transmitted type II diabetes mellitus and deafness. Nat Genet 1: 368-371

3. Karvonen M, Tuomilehto J, Libman I, LaPorte R for the World Health Organization DIAMOND project group (1993) A review of the recent epidemiological data on the 
worldwide incidence of Type 1 (insulin-dependent) diabetes mellitus. Diabetologia 36: 883-892

4. World Health Organization, Study Group on Diabetes Mellitus (1985) WHO, Geneva, Technical Report Series No 727

5. Lehto M, Tuomi T, Mahtani M et al. (1997) Characterization of the MODY3 phenotype: Early-onset diabetes caused by an insulin secretion defect. J Clin Invest 99: 582-591

6. Lehto M, Bitzén P-O, Isomaa B et al. (1999) Mutation in the HNF-4 $\alpha$ gene affects insulin secretion and triglyceride metabolism. Diabetes 48: 423-425

7. Yamagata K, Oda N, Kaisaki PJ et al. (1996) Mutations in the hepatocyte nuclear factor- $1 \alpha$ gene in maturity-onset diabetes of the young (MODY3). Nature 384: 455-458

8. Yoshiuchi I, Yamagata K, Yang Q et al. (1999) Three new mutations in the hepatocyte nuclear factor- $1 \alpha$ gene in Japanese subjects with diabetes mellitus: clinical features and functional characterization. Diabetologia 42: 621-626

9. Blohmé G, Nyström L, Arnqvist HJ et al. (1992) Male predominance of Type 1 (insulin-dependent) diabetes mellitus in young adults: results from a 5-year prospective nationwide study of the 15-34-year age group in Sweden. Diabetologia 35: 56-62

10. Urhammer SA, Fridberg M, Hansen Tet al. (1997) A prevalent amino acid polymorphism at codon 98 in the hepatocyte nuclear factor- 1 a gene is associated with reduced se- rum C-peptide and insulin responses to an oral glucose challenge. Diabetes 46: 912-916

11. Tuomi T, Carlsson $\AA$, Li H et al. (1999) Clinical and genetic characteristics of type 2 diabetes with and without GAD antibodies. Diabetes 48: 150-157

12. Yamada S, Nishigori H, Onda H et al. (1997) Identification of mutations in the hepatocyte nuclear factor (HNF)- $1 \alpha$ gene in Japanese subjects with IDDM. Diabetes 46: 1643-1647

13. Moller AM, Dalgaard LT, Pociot F, Nerup J, Hansen T, Pedersen O (1998) Mutations in the hepatocyte nuclear factor- $1 \alpha$ gene in Caucasian families originally classified as having Type I diabetes. Diabetologia 41: 1528-1531

14. Glucksmann MA, Lehto M, Tayber O et al. (1997) Novel mutations and a mutational hotspot in the MODY3 gene. Diabetes 46: 1081-1086

15. Chévre J-C, Hani EH, Boutin P et al. (1998) Mutation screening in 18 Caucasian families suggest the existence of other MODY genes. Diabetologia 41: 1017-1023

16. Hara M, Lindner TH, Paz VP et al. (1998) Mutations in the coding region of the insulin promoter factor 1 gene are not a common cause of maturity-onset diabetes of the young in Japanese subjects. Diabetes 47: 845-846

17. Beards F, Frayling T, Bulman M et al. (1998) Mutations in hepatocyte nuclear factor $1 \beta$ are not a common cause of maturity-onset diabetes of the young in the U.K. Diabetes 47: $1152-1154$ 